\title{
Methyl bromide terminology
}

Barrier films (low-permeability plastics): Gasimpermeable films that reduce fumigant emissions, increase fumigant retention and, in some cases, lower the dose needed for pest control. The traditional plastic tarp used in fumigation, HDPE, reduces fumigant emissions by about $50 \%$. The recently developed virtually impermeable film (VIF) is more effective, and totally impermeable film (TIF) is the most effective.

\section{Broadcast shank fumigation (or flat fumiga-} tion): Traditional strawberry field fumigation that began in the 1960s, in which growers applied MB combined with chloropicrin to entire fields, which are covered with polyethylene film to hold in the fumigant at concentrations needed to kill soil pests.

Buffer zones: Nonfumigated areas that separate the fumigated field from bystanders. Zones are designed to minimize exposure to people who are not directly associated with fumigant application (other agricultural workers and the general public). The size of the buffer zone is determined by fumigation method, field size and application rate. Large buffer zones, required for large fields or high application rates, complicate or prevent the treatment of some fields.

Chemigation: Irrigation applied with a fumigant, fertilizer or other water soluble agricultural input. Chemigation is used in a wide variety of crops and with different kinds of irrigation. For example,

\section{Common acronyms}

1,3-D: 1,3-dichloropropene

CUE: critical use exemption

DMDS: dimethyl disulfide

DFC: dynamic flux chamber

EVOH: ethyl vinyl alcohol resin vapor-barrier layer

HDPE: high-density polyethylene

ISCST3: Industrial Source Complex Short Term, version 3 Dispersion Model

MB: methyl bromide

MITC: methyl isothiocyanate

MTC: mass transfer coefficient $\left(\mathrm{cm} \mathrm{h}^{-1}\right)$

MB + Pic: methyl bromide plus chloropicrin

MB:Pic: methyl bromide with chloropicrin (98:2, 67:33 or $50: 50)$

Pic: chloropicrin

Pic-Clor 60: fumigant product containing 60\% chloropicrin and 39\% 1,3-D

Pic-EC: chloropicrin emulsified formulation QPS: quarantine and preshipment (exemption) SF: sulfuryl fluoride

RABET: raised bed trough system

RED: Reregistration eligibility decision

TIF: totally impermeable film

VIF: virtually impermeable film it is used to drip fumigate strawberry fields for the control of pathogens, nematodes and weed seeds. Because chloropicrin and 1,3-D are less volatile than MB, they can be applied to raised beds through drip systems and have been shown to be effective in controlling most soilborne pathogens and weed seeds, resulting in comparable strawberry yields.

Critical use exemptions (CUEs): Allowances for production or import of $\mathrm{MB}$ in the absence of technically or economically feasible alternatives (see page 121).

Low permeability films: The traditional plastic tarp used in fumigation, HDPE, has much greater permeability than the newly developed films (VIF and TIF) and only reduces fumigant emissions by approximately $50 \%$.

Non-attainment area (NAA): Any area that does not meet (or that contributes to ambient air quality in a nearby area that does not meet) the national primary or secondary ambient air quality standard for the pollutant. Such an area has air quality worse than the National Ambient Air Quality Standards as defined in the Clean Air Act Amendments of 1970. NAAs must have and implement a plan to meet the standard, or risk losing federal financial assistance. An area may be an NAA for one pollutant and an attainment area for others.

Ozone depleting substances (ODSs): In the United States, ODSs are regulated as Class I or Class II controlled substances. Class I substances have a higher ozone-depleting potential and have been completely phased out in the United States, except for exemptions allowed under the Montreal Protocol. They were subject to the first round of phase-out targets, have an ozone depletion potential (ODP) of 0.2 or higher, and include MB.

Phase-out of ODSs: EPA regulations issued under the Clean Air Act phase out the production and import of ODSs, consistent with schedules under the Montreal Protocol (see page 121).

\section{Quarantine and preshipment exemptions}

(QPSs): Quarantine applications, with respect to $\mathrm{MB}$, are treatments to prevent the introduction, establishment and/or spread of quarantine pests (including diseases), or to ensure their official control. Preshipment applications are those nonquarantine applications within 21 days prior to export to meet the official requirements of the importing country or the existing official requirements of the exporting country.

\section{Reregistration eligibility decisions (REDs):} In 2004, the EPA began reviewing the human health and environmental impact of fumigants that were registered prior to November 1984. REDs describe new or modified labeling requirements regarding fumigant rates, application methods, buffer zone requirements, neighbor notification and worker safety standards. One controversial aspect of these rules is the size of the required buffer zone around fumigated fields.

Stratosphere: Upper atmosphere, from 11 to 31 miles above earth's surface, where the ozone layer screens damaging ultraviolet light from the sun.

Totally impermeable (plastic) film (TIF): A relatively new barrier, TIF has been shown to be the most effective in fumigant retention. TIF is a multilayer film that includes one or more low-permeability layers, such as ethylene vinyl alcohol layers, as well as layers of standard polyethylene film.

Township cap/limit: The California Department of Pesticide Regulation (DPR) restricts levels of certain pesticides in ambient air within 36-square-mile areas known as townships. In California, 1,3-D is limited to 90,250 pounds per 36-square-mile township.

Troposphere: Lower atmosphere where air pollution develops, from the surface to 11 miles in altitude. Pollutants include ozone and particulate matter. VOCs contribute to the formation of some pollutants.

Virtually impermeable film (VIF): Although more permeable than TIF, VIF plastic film can reduce fumigant emissions and enhance their distribution in soil, in comparison with conventional polyethylene films. VIF differs from traditional high-density polyethylene tarps in that it has additional gas-impermeable layers, e.g., nylon or polyamides, between the polyethylene layers.

Volatile organic compounds (VOCs): Carbonbased compounds that contribute to formation of atmospheric photochemical smog. Under provisions of the U.S. Clean Air Act, the DPR must reduce agricultural emissions of smog-forming VOCs from soil fumigants and other pesticides. Regulations restrict fumigation from May 1 to Oct. 31 in NAAs.

(Information compiled from online sources; from authors Husein Ajwa, Greg Browne, Steve Fennimore and Jerry Weiland, and from Randy Segawa, Environmental Program Manager, Air and Ground Water Programs California DPR. - J. White)

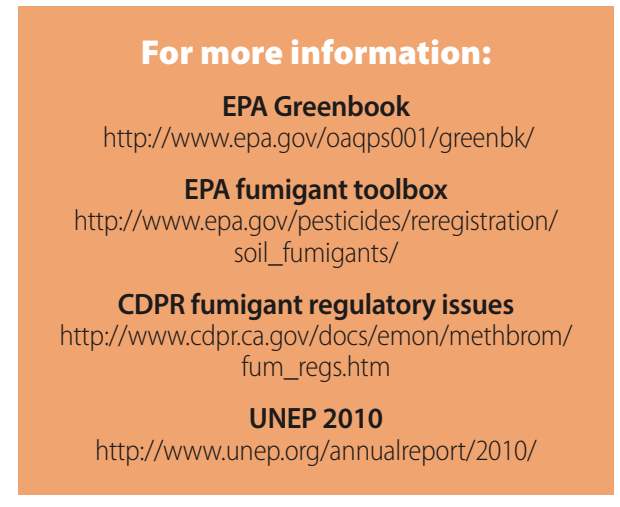

